\title{
The Role of Zinc, Manganse and Copper in Rumen Metabolism and Immune Function: A Review Article
}

\author{
Elhashmi Y. Hilal', Mohamed A. E. Elkhairey1,2*, Ayman 0. A. Osman1 \\ ${ }^{1}$ Faculty of Animal Production, University of Gezira, Gezira, Al-Managil, Sudan \\ ${ }^{2}$ College of Animal Science and Technology, Northwest A \& F University, Yangling, China \\ Email: ^elkhairey11@yahoo.com
}

How to cite this paper: Hilal, E.Y., Elkhairey, M.A.E. and Osman, A.O.A. (2016) The Role of Zinc, Manganse and Copper in Rumen Metabolism and Immune Function: A Review Article. Open Journal of Anima Sciences, 6, 304-324. http://dx.doi.org/10.4236/ojas.2016.64035

Received: May 19, 2016

Accepted: October 28, 2016

Published: October 31, 2016

Copyright $\odot 2016$ by authors and Scientific Research Publishing Inc. This work is licensed under the Creative Commons Attribution International License (CC BY 4.0).

http://creativecommons.org/licenses/by/4.0/ (c) (i) Open Access

\begin{abstract}
Trace minerals are dietary elements required by the body in minute amounts, ranging from 0.10 to $50.0 \mathrm{mg} / \mathrm{kg}$ dry matter in beef cattle diets [1]. These trace minerals are all necessary for the biochemical processes of the body that support proper growth and maintenance. For example, $\mathrm{Cu}$ is necessary for the function of superoxide dismutase and its removal of toxic byproducts from metabolic pathways [2]. The removal of these toxic byproducts allows for metabolism to proceed efficiently, uninhibited by damaging oxygen free radicals. Zinc, an important trace mineral for enzyme function, aides in the regulation of nucleic acid production, carbohydrate metabolism, and protein synthesis, thus providing a stable framework for development [3]. The immune system is part of the host's defense against destructive forces from outside the body, such as bacteria, viruses, and parasites, or from within, such as malignant cells or those that produce autoantibodies [4]. This system is composed of two branches: the innate or non-specific immune system, and the adaptive or specific immune system [5]. In this review paper, an attempt has been made to review effects of mineral supplements in Rumen Metabolism, effects on Immune Function in different species of animals.
\end{abstract}

\section{Keywords}

Dietary Trace Mineral, Rumen Metabolism, Immune Function, Performance, Reproductive and Rumen Fermentation

\section{Introduction}

At present time, 111 chemical elements are officially accepted by the International Un- 
ion of Pure and Applied Chemistry [6]. Out of them, 93 are classified as naturally occurring, and approximately 50 have been identified as useful to sustain a normal health status in mammals. In addition to the six core elements $(\mathrm{C}, \mathrm{H}, \mathrm{N}, \mathrm{O}, \mathrm{S}$ and $\mathrm{P})$ that make up nucleic acids, proteins, carbohydrates, and lipids and thus the bulk of living matter [7], many other elements are essential to the nutritional requirements of superior animals. Minerals required in relatively large quantities (g/d) are named "macro" minerals. In opposition, minerals required in mg or $\mu$ g amounts are referred to as "micro" or "trace" minerals [1]. Minerals are usually classified into four broad groups according to their physiological roles:

- Structural: minerals forming structural components of the body organs and tissues which include $\mathrm{Ca}, \mathrm{P}, \mathrm{Mg}, \mathrm{Fl}$ and $\mathrm{Si}$ in bones and teeth and $\mathrm{P}$ and $\mathrm{S}$ in muscle proteins.

- Physiological: minerals occurring on body fluids and tissues as electrolytes, involved in the maintenance of osmotic pressure, acid base-equilibrium, membrane permeability and tissue stimuli (e.g. $\mathrm{Na}, \mathrm{K}, \mathrm{Cl}, \mathrm{Ca}$ and $\mathrm{Mg}$ in blood and cerebrospinal fluid).

- Catalytic: minerals acting as catalysts in enzymatic systems, as integral compounds in the structure of metalloenzymes or as cofactors required for enzymatic activation (e.g. $\mathrm{Fe}, \mathrm{Cu}, \mathrm{Zn}, \mathrm{Mn}$, and Se involved in cytochromes, ceruloplasmin, carbonic anhydrase, pyruvate carboxylase, and glutathione peroxidase, respectively).

- Regulatory: minerals involved in regulation of cell replication and differentiation (e.g. Ca, in signaling transduction; $\mathrm{Zn}$, in DNA transcription).

However, this classification is arbitrary and not exclusive since the same element can fulfill more than a single function [8].

Ideally, dietary supply of minerals to livestock must be sufficient to ensure the maintenance of body reserves, and to provide adequate concentrations in edible products. However, in some occasions, drinking water can be an exceptionally rich source of minerals, sometimes responsible for mineral toxicity [9]. The accomplishment of an adequate supply of minerals is especially challenging since requirements for most minerals are not constant, but affected by physiological factors including genetics, age, sex, type of production (maintenance, growth, reproduction, and lactation), and level of production [10].

\section{Availability of Minerals to Animals}

The evaluation of feedstuffs and mineral supplements for the host animal depends not only on the mineral content in the sources but also on the potential availability and absorption of the minerals from the gastrointestinal tract and the mineral's utilization by the animal tissues [11]. However the potentially absorbable fraction of a mineral is greatly influenced by several factor including age and species of animal, intake of mineral relative to amount required, chemical form of the mineral, and the amount and proportions of other dietary compounds involved in specific interactions with the mineral [12]. Livestock diets are often supplemented with trace minerals in the form of inorganic salts, usually oxides, chlorides, sulfates and carbonates. In recent years there has been considerable interest in the use of organic trace minerals in ruminant diets 
[13]. According to the Association of American Feed Control Officials [14], organic trace minerals in the United States are available in one of the following forms:

- Metal Proteinate: the product resulting from the chelation of a soluble salt with amino acids and/or partially hydrolyzed protein, e.g. Cu proteinate, $\mathrm{Zn}$ proteinate, Co proteinate and Mn proteinate.

- Metal Amino Acid Chelate: the product resulting from the reaction of a metal ion from a soluble metal salt with amino acids with a mole ratio of one mole of metal to one to three (preferably two) moles of amino acids forming coordinate covalent bonds. For example, $\mathrm{Cu}$-lysine-sulfate is the sulfate salt of 2:1 molar ratio of L-lysine and $\mathrm{Cu}$. Similarly $\mathrm{Cu}$ methionine-bisulfate is the bisulfate salt of a 1:1 molar ratio of DL-methionine and $\mathrm{Cu}$. Other commercially available metal amino acids are $\mathrm{Cu}$ amino acid chelate, $\mathrm{Zn}$ amino acid chelate and $\mathrm{Mn}$ amino acid chelate in addition to chelates for macro minerals like $\mathrm{Ca}$ and $\mathrm{Mg}$.

- Metal Amino Acid Complex: the product resulting from complexing a soluble metal salt with an amino acid. Commercially available metal complexes are Zn-methionine, $\mathrm{Zn}$-lysine, $\mathrm{Mn}$-methionine, $\mathrm{Fe}$-methionine and $\mathrm{Cu}$-lysine.

- Metal Polysaccharide Complex: the product resulting from complexing a soluble salt with a polysaccharide solution declared as an ingredient of the formulation (e.g. $\mathrm{Cu}$ polysaccharide complex, $\mathrm{Zn}$ polysaccharide complex, etc).

While the effectiveness of organic minerals for ruminants has been strongly criticized [9] [15] established that for chelation to be effective, the chelating agent should have a stronger stability for the metal than the metal binding substances in feed, but smaller stability constant than the tissue system where the metal is required. In addition, other factors including metal ion equilibria, kinetic factors, $\mathrm{pH}$ gradients and redox equilibrium (in case of redox active metals such as $\mathrm{Cu}^{2+}$ ), may also affect the uptake mechanism of metal ions [16]. Several studies have been conducted to address the benefits of including organic sources of minerals on the productive performance of ruminants. However, in many cases a combination of several organic elements has been used, making difficult to assess which one is responsible for the effects noticed, as discussed later.

The aim of this review is to explore the factors involved in bioavailability of $\mathrm{Zn}, \mathrm{Mn}$ and $\mathrm{Cu}$ at the gastrointestinal tract, affecting the mineral status of the host animal. In addition, the role of $\mathrm{Zn}, \mathrm{Mn}$ and $\mathrm{Cu}$ on ruminal physiology is presented.

\section{Zinc}

\subsection{Interaction of Zinc with Dietary Factors}

Early studies from [17] showed that in ruminants, the percentage of dietary $\mathrm{Zn}$ absorbed decreases as dietary $\mathrm{Zn}$ increases. [18] found a linear increment in endogenous fecal loss of $\mathrm{Zn}$ when rats were feed increasing levels of dietary $\mathrm{Zn}$ ranging from 0 to $8400 \mathrm{ppm}$. Similarly, in a study conducted in growing pigs receiving $67 \mathrm{Zn}$, the addition of phytase increased $\mathrm{Zn}$ absorption but also resulted in higher endogenous fecal loss [19]. Concurrently, reductions of urinary and fecal $\mathrm{Zn}$ excretion by $48 \%$ and $46 \%$, respectively were found in humans when dietary $\mathrm{Zn}$ was reduced from 85 to $12 \mu \mathrm{mol} / \mathrm{d}$. 
Despite the influence of dietary levels, the requirement of $\mathrm{Zn}$ appears to be affected by other dietary factors. However, all of the factors and interactions that play a role on $\mathrm{Zn}$ bioavailability are not clearly defined [20]. According to [21], the two major dietary factors affecting $\mathrm{Zn}$ bioavailability are the presence of organic chelating agents and the interaction with metallic ions, with $\mathrm{Cu}$ and $\mathrm{Ca}$ being the most important antagonists.

\subsection{Role of Zinc on Rumen Fermentation}

Early studies from [22] showed that in vitro microbial protein synthesis was increased together with a reduction in $\mathrm{NH}_{3}-\mathrm{N}$ concentration when rumen fluid was incubated with additional $\mathrm{Zn}$ as $\mathrm{ZnCl}_{2}$ or $\mathrm{ZnSO}_{4}$. According to the authors, this response is due to an effect of $\mathrm{Zn}$ in increasing microbial enzymatic activity. However, further studies from [23] showed differences in the behavior of rumen microbial populations in the presence of $\mathrm{Zn}$. While protozoa easily incorporated $\mathrm{Zn}$ and were tolerant to high $\mathrm{Zn}$ concentrations $(25 \mu \mathrm{g} / \mathrm{mL})$, cellulose degradation from rumen bacteria was deeply depressed, along with bacterial urease activity. In partial agreement, [24] found that addition of $5 \mu \mathrm{g} \mathrm{Zn} / \mathrm{mL}$ of rumen fluid increased cellulose digestion by $24 \%$, but addition of $20 \mu \mathrm{g} / \mathrm{mL}$ of $\mathrm{Zn}$ depressed it by $31 \%$. [25] found that low supplementation levels (10 to $15 \mathrm{ppm} \mathrm{Zn}$ in incubation fluid) inhibited in vitro urea hydrolysis and retarded ammonia accumulation. Similarly, when $\mathrm{Zn}$ was added in vivo at $250 \mathrm{ppm} \mathrm{Zn}$ on DM basis, molar proportion of propionate was increased with the consequent decrease in acetate: propionate ratio, and rumen ammonia was decreased due to microbial urease inhibition. However, when $\mathrm{Zn}$ was added to achieve a level of 470 ppm on DM basis, a tendency for depressed DM digestibility was noticed. In addition, [26] found a decrease in total VFA when $\mathrm{Zn}$ was provided to steers as $\mathrm{Zn}$ methionine or $\mathrm{Zn}$ glycine compared with $\mathrm{ZnSO}_{4}$ at concentrations closer to physiological levels (20 ppm). In the same study, molar proportion of propionate was increased by $\mathrm{Zn}$ methionine and that of butyrate was decreased, with the consequent reduction in the acetate: propionate ratio. The authors conclude that supplementation of $\mathrm{Zn}$ methionine may alter ruminal fermentation.

While these differences can be partially explained by the dose of $\mathrm{Zn}$ and the fermentation substrate used by the different authors, an alternative mechanism is proposed by [27], who found that addition of $50 \mu \mathrm{g} / \mathrm{mL}$ of $\mathrm{Zn}$ to in vitro incubations decreased cellulose digestion at $24 \mathrm{~h}$, but not at $48 \mathrm{~h}$, resulting in an overall decrease in the rate, but not the extent of digestion. The authors conclude that the initial decrease in cellulose digestion might be related to a direct effect of $\mathrm{Zn}$ on inactivation of bacterial cellulase, since heavy metal salts can precipitate and denature soluble proteins and enzymes. However, enough cellulase activity may be present to overcome those negative effects of high $\mathrm{Zn}$ concentrations. In addition, the accumulation of $\mathrm{Zn}$ in bacterial wall [28] might be affecting the adhesion of microbial cells to cellulose particles, a limiting step in cellulose fermentation as previously established [29].

\subsection{Zinc Availability from Organic and Inorganic Sources}

There is scientific evidence showing that organic $\mathrm{Zn}$ is metabolized differently than in- 
organic sources. In four consecutive studies conducted by [30], $\mathrm{Zn}$ was better retained when added as $\mathrm{Zn}$ methionine than $\mathrm{ZnO}$ in lambs and heifers. However, the observed improvement was not due to higher absorption but to a lower urinary $\mathrm{Zn}$ excretion in animals receiving $\mathrm{Zn}$ methionine, and only minor changes in blood parameters were noticed. Similarly, in a study conducted by [31] in calves, organic or inorganic Zn supplementation did not affect concentration of serum enzymes (alkaline phosphatase, glutamate oxaloacetate transaminase, glutamate pyruvate transaminase and super oxide dismutase) or mean concentrations of different serum vitamins (retinol, $\beta$-carotene, $\alpha$-tocopherol) and hormones (triiodothyronine, thyroxin, insulin and testosterone). Furthermore, blood parameters from supplemented groups did not differ from unsupplemented controls. In a comparative study, [32] found no differences in liver $\mathrm{Zn}$ and plasma $\mathrm{Zn}$ concentration of steers receiving $\mathrm{ZnSO}_{4}$ or $\mathrm{Zn}$ amino acid complex. However, confounding effects may account for these findings, given the differences in mineral status of the animals at the beginning of the study. In partial agreement, no differences in plasma $\mathrm{Zn}$ concentration of steers receiving $\mathrm{ZnSO}_{4}, \mathrm{Zn}$ methionine complex or $\mathrm{Zn}$ glycine were found by [26]. Although large variations prevented from obtaining differences in absorbed or retained $\mathrm{Zn}, \mathrm{Zn}$ glycine resulted in larger liver $\mathrm{Zn}$ concentrations. Conversely, using organic and inorganic $\mathrm{Zn}$. [33] found higher concentrations of $\mathrm{Zn}$ in plasma of supplemented beef steers than in controls, despite the $\mathrm{Zn}$ source. Interestingly, in animals receiving an implant containing estradiol benzoate and testosterone propionate, weight gain resulted higher when $\mathrm{Zn}$ was supplemented as $\mathrm{ZnSO}_{4}$ that of $\mathrm{Zn}$ propionate [33]. In a large production study including 250 dairy cows, only a tendency for improvement in milk production was obtained when $\mathrm{Cu}, \mathrm{Zn}, \mathrm{Mn}$ and $\mathrm{Co}$ as sulfates, were replaced by organic forms of the minerals. Liver concentration of minerals was unaffected by mineral source, but supplementation with organic minerals resulted in increased milk solids and a decreased incidence of sole ulcers [34]. In another large scale study conducted on 573 dairy cows [35], supplementing $75 \%$ of the requirement of $\mathrm{Zn}$ as $\mathrm{Zn}$ methionine achieved the same hepatic $\mathrm{Zn}$ concentration than supplementing $100 \%$ of the requirement as $\mathrm{ZnSO}_{4}$. Based on the lack of differences in health and productive performance the authors suggest that mineral content of liver is not an accurate predictor of cow's response to different sources and levels of trace minerals. In agreement, [34] suggest that $\mathrm{Zn}, \mathrm{Mn}$, and $\mathrm{Cu}$ content of liver is a poor indicator of trace mineral status. According to [2], the supposed benefits of organic sources of $\mathrm{Zn}$ on $\mathrm{Zn}$ availability claimed in studies conducted in monogastrics cannot be adopted in ruminants since phytic acid, a major antagonist of $\mathrm{Zn}$ absorption, is largely hydrolyzed in the rumen. An additional difficulty in the evaluation of $\mathrm{Zn}$ availability from different sources relies on the fact that $\mathrm{Zn}$ is absorbed according to the animal needs and homoeostasis in ruminants is achieved primarily by control of intestinal absorption [36].

\section{Manganese}

\subsection{Interaction of Manganese with Dietary Factors}

According to the [1], there is no exact data regarding the maintenance requirements of 
$\mathrm{Mn}$ in dairy cattle. However, the coefficient of intestinal absorption for $\mathrm{Mn}$ in adult cattle is known to be as low as $1 \%$ of ingested Mn or even lower $(37 ; 20)$, but the absorption in young calves is considerably higher [37]. Despite the generalized idea of poor Mn absorption, [8] suggested that this situation is partly a reflection of the substantial surplus of Mn provided by most practical rations, since higher coefficients of absorption were obtained when animals received diets marginal in $\mathrm{Mn}$ [38]. For this reason, the [1] adopted a conservative coefficient of $0.75 \%$ for Mn absorption. In agreement, [39] reported a coefficient of $0.54 \%$ for Mn absorption in dairy cows. The study of dietary factors influencing $\mathrm{Mn}$ bioavailability has received little attention, probably because $\mathrm{Mn}$ deficiency is not considered to be a major problem in ruminants [20]. In addition, most of the information available has been generated in monogastric models. [40] observed a $10 \%$ and $13 \%$ increase in kidney and bone Mn, respectively from chicks receiving $12 \mathrm{ppm}$ of virginiamycin in the diet. In a further study [41], the addition of 4 ppm lincomycin resulted in higher concentrations of $\mathrm{Mn}$ in bone. However, while virginiamycin and other antibiotics are currently used as feed additives for ruminants [42], their role in Mn absorption in cattle remains unknown. According to [43], the intestinal absorption of $\mathrm{Mn}$ is negatively affected by dietary levels of $\mathrm{Ca}$ and P. Similar results were found by [44], who found a $45 \%$ reduction in $\mathrm{Mn}$ in the tibia of chicks fed excess $\mathrm{Ca}$ and $\mathrm{P}$. However, further evidence provided by [45] indicated that while $\mathrm{P}$ has a negative effect on $\mathrm{Mn}$ absorption, no deleterious effects on Mn metabolism are obtained with excess of dietary $\mathrm{Ca}$, but effects of $\mathrm{Ca}$ and $\mathrm{P}$ are difficult to distinguish since diets are usually enriched with both minerals to maintain a Ca:P physiological ratio [9]. There have been no reports relating Mn absorption with forage composition in ruminants, but phytate and fiber are known to be the main antagonists in monogastrics species including human [46], swine [47]. Through microbial activity, both phytates and fiber are broken down in rumen [48]. For that reason, [9] suggests that $\mathrm{Mn}$ absorption in ruminants may not be affected by the presence of phytates, being higher than that usually reported for monogastrics.

\subsection{Role of Manganese on Rumen Fermentation}

Limited information is available regarding the role of $\mathrm{Mn}$ in rumen fermentation. According to [49], Mn has a slight stimulatory effect on urease activity. [25] reported a 6\% increment in IVDMD when Mn was added to incubations at a dose of $100 \mathrm{ppm}$. In a previous study, [50] found a reduction in cellulose digestion when Mn was omitted from in vitro incubations. However, [24] reported that cellulose digestion peaked at $\mathrm{Mn}$ concentrations of 10 to $20 \mathrm{ppm}$ but was completely abolished when Mn was added at 300 ppm. Using $54 \mathrm{Mn}$, [51] [52] observed that Mn accumulation was higher in rumen bacterial cell walls than in cytoplasm, and that the uptake was similar in bacteria and protozoa, but the biological implications of this fact are not established. [53] fed ram lambs diets that contained from 13 to $45 \mathrm{mg}$ of $\mathrm{Mn} / \mathrm{kg}$ DM during 84 days. While the number of rumen bacteria was not affected by $\mathrm{Mn}$, the large rumen bacteria (identified as those with a diameter of 12.9 to $16.2 \mu \mathrm{m}$ ) resulted lower with the lowest Mn intake 
and highest with dietary $\mathrm{Mn}$ provided at $30 \mathrm{mg} / \mathrm{kg}$. This may be particularly relevant since large rumen bacteria contain more protein than small rumen bacteria [54]. However, despite this variation in microbial populations, no effect of Mn on DM digestibility was observed. [55] suggested that sheep consuming a diet high in fiber and low in protein may respond to $\mathrm{Mn}$ supplementation in excess of $36 \mu \mathrm{g} / \mathrm{g} \mathrm{DM}$, but Mn requirements of the rumen microbes may be increased by the consumption of low quality roughages. In agreement, [56] suggest that the optimum content of $\mathrm{Mn}$ in the diet may be as high as $120 \mu \mathrm{g} / \mathrm{g} \mathrm{DM}$ on the basis of results from in vitro studies.

\subsection{Manganese Availability from Organic and Inorganic Sources}

The aim of mineral supplementation is to increase the biological availability of the target mineral(s), defined as the degree to which an ingested element is absorbed and can be utilized in metabolism by the animal [57]. Different sources of Mn are currently available as supplements for animal diets. Among the inorganic sources, the most commonly used include manganese carbonate $\left(\mathrm{MnCO}_{3}\right)$, hausmannite $\left(\mathrm{Mn}_{3} \mathrm{O}_{4}\right)$, manganese oxide $(\mathrm{MnO})$, manganese dioxide $\left(\mathrm{MnO}_{2}\right)$, manganite $\left(\mathrm{Mn}_{2} \mathrm{O}_{3}\right)$, manganous chloride $\left(\mathrm{MnCl}_{2} \cdot 4 \mathrm{H}_{2} \mathrm{O}\right)$ and manganese sulfate $\left(\mathrm{MnSO}_{4}\right)$ [8] [58] [59] [60]. Conversely, sources of $\mathrm{Mn}$ classified as "organic" include Mn-methionine, Mn-proteinate and Mn-polysaccharide [42] [61] [62] [63]. Unfortunately, only few studies have been conducted comparing the relative bioavailability of $\mathrm{Mn}$ sources in ruminants fed physiological concentrations of $\mathrm{Mn}$ [64]. According to [65], some chelates and complexes may improve the mineral bioavailability above that of soluble inorganic forms, as later shown by [42] in lambs comparing Mn-methionine with MnO. However, no differences were obtained in the same study when $\mathrm{Mn}$-methionine was compared with $\mathrm{MnSO}_{4}$. Similarly, [66] compared the bioavailability of $\mathrm{Mn}$ from different organic sources and $\mathrm{MnSO}_{4}$ in broilers. The authors concluded that only organic Mn sources with moderate or strong chelation strength can provide higher relative bioavailabilities due to their ability to resist $\mathrm{Ca}$ antagonisms during the digestion process. In addition, studies conducted on female chicks showed an increase in Mn retention from a Mn-methionine chelate compared with $\mathrm{MnO}$ [67].

\section{Copper}

\subsection{Interaction of Copper with Dietary Factors}

The amount of dietary $\mathrm{Cu}$ needed to supply $\mathrm{Cu}$ requirements for maintenance, growth and lactation varies with the age of the animal, the chemical form of dietary $\mathrm{Cu}$ and the presence of dietary substances interfering with $\mathrm{Cu}$ absorption [1]. Compared with monogastrics where $\mathrm{Cu}$ is fairly well absorbed $(30 \%-75 \%)$, absorption in adult ruminants is low, ranging from $1 \%$ to $10 \%$ of dietary $\mathrm{Cu}$ [8] [68]. However, before developing a functional rumen, $\mathrm{Cu}$ absorption in lambs can be as high as $70-85 \%$ of the dietary supply [69]. The reason for this decrease in $\mathrm{Cu}$ absorption appears to be related to interactions occurring at the rumen environment, including the Cu-S-Mo [9] [70] [71], $\mathrm{Cu}-\mathrm{S}$ [72] [73], and $\mathrm{Cu}-\mathrm{Fe}$ [74] [75] antagonisms. More recently, results relating high 
levels of dietary $\mathrm{Mn}$ with $\mathrm{Cu}$ deficiency have been reported [76] [77].

\subsection{Copper-Molybdenum-Sulfur Interaction}

In the presence of ruminal $\mathrm{H}^{+}$ions, dietary $\mathrm{S}$ is reduced to sulfide, which then reacts with Mo [78] to form different thiomolybdates (mono-, di-, tri-, tetra-thiomolybdates) according to the following reactions:

$$
\begin{gathered}
\mathrm{MoO}_{4}^{2-}+\mathrm{H}^{+}+\mathrm{HS}^{-} \leftrightarrow \mathrm{H}_{2} \mathrm{O}+\mathrm{MoO}_{3} \mathrm{~S}^{2-} \text { (monothiomolybdate) } \\
\mathrm{MoO}_{3} \mathrm{~S}^{2-}+\mathrm{H}^{+}+\mathrm{HS}^{-} \leftrightarrow \mathrm{H}_{2} \mathrm{O}+\mathrm{MoO}_{3} \mathrm{~S}_{2}^{2-} \quad \text { (dithiomolybdate) } \\
\mathrm{MoO}_{2} \mathrm{~S}_{2}^{-}+\mathrm{H}^{+}+\mathrm{HS}^{-} \leftrightarrow \mathrm{H}_{2} \mathrm{O}+\mathrm{MoO}_{3} \mathrm{~S}_{3}^{2-} \text { (trithiomolybdate) } \\
\mathrm{MoO}_{3}^{2-}+\mathrm{H}^{+}+\mathrm{HS}^{-} \leftrightarrow \mathrm{H}_{2} \mathrm{O}+\mathrm{MoS}_{4}^{2-} \text { (tetrathiomolybdate) }
\end{gathered}
$$

In the gastrointestinal tract, thiomolybdates have been shown to bind $\mathrm{Cu}$ preventing its absorption, while increasing the $\mathrm{Cu}$ fraction associated with the solid phase of the rumen content at expense of a reduction in the fluid phase. Thiomolybdates associated with solid rumen digesta (bacteria, protozoa, and indigested feed particles) form insoluble complexes that do not release $\mathrm{Cu}$ even under acidic conditions like the abomasal environment [79]. In addition, absorbed thiomolybdates have also been shown to cause systemic effects on $\mathrm{Cu}$ metabolism including increased biliary excretion of $\mathrm{Cu}$ from liver stores, strong binding of $\mathrm{Cu}$ to plasma albumin resulting in reduced availability for biochemical processes, and inhibition of $\mathrm{Cu}$ dependent metalloenzymes such as ceruloplasmin, diamine oxidase, cytochrome oxidase, ascorbate oxidase and tyrosine oxidase. [20] [78] [80]. According to [20], when rumen sulfide concentrations are low, Mo has little effect on the formation of thiomolybdates. However, $\mathrm{Cu}$ bioavailability is deeply reduced (up to 70\%) when Mo levels are not modified but sulfide concentrations are increased [81].

\subsection{Copper-Sulfur Interaction}

In addition to its role in the $\mathrm{Cu}-\mathrm{Mo}-\mathrm{S}$ interaction, organic or inorganic $\mathrm{S}$ can also reduce $\mathrm{Cu}$ bioavailability per-se [21]. [82] found a 55\% reduction in hepatic $\mathrm{Cu}$ when sheep were fed high levels of S ( $2 \mathrm{~g} / \mathrm{kg} \mathrm{DM})$. According to the authors, this reduction was due to formation of $\mathrm{CuS}$ in the digestive tract, since the diet was very low in Mo. Similar results were previously observed by [72] who found a $39 \%-56 \%$ reduction in $\mathrm{Cu}$ bioavailability when $\mathrm{S}$ was provided to ewes as methionine or as $\mathrm{NaSO}_{4}$ under low Mo dietary levels, possibly through the formation of insoluble $\mathrm{CuS}$ at sites beyond the rumen. However, [83] postulates that the formation of insoluble $\mathrm{CuS}$ and $\mathrm{Cu}_{2} \mathrm{~S}$ in the rumen is exacerbated by the digestion of insoluble proteins by protozoa, with the consequent increase in available $S$. Despite the effect of dietary $S$ previously mentioned, other $\mathrm{S}$ sources have been also responsible for decreasing $\mathrm{Cu}$ bioavailability in ruminants. Molasses, a by-product from the sugarcane and beet industry, is a source of dietary sugars feed to dairy cows [1]. Benefits of adding molasses to diets include increasing palatability, acting as a binder, and reducing dust in fine-particle feeds [84]. How- 
ever, due to its high content of S, the liberal use of molasses can result in dietary S levels considerably in excess of requirements [85]. [73] evidenced a decrease in liver $\mathrm{Cu}$ at 29, 56 or $84 \mathrm{~d}$ after feeding heifers with a molasses based supplement. According to the authors, this observation was the result of high concentrations of $S$ naturally found in molasses.

In a review of $\mathrm{Cu}$ antagonists in cattle, [86] describes other sources of $\mathrm{S}$ implicated in the $\mathrm{Cu}-\mathrm{Mo}-\mathrm{S}$ and $\mathrm{Cu}-\mathrm{S}$ interactions, included fertilizers, high $\mathrm{S}$ water, and $\mathrm{S}$ containing supplements. Cows grazing bahiagrass pastures fertilized with ammonium sulfate showed lower liver $\mathrm{Cu}$ concentrations compared with cows on non fertilized pastures, or fertilized with ammonium nitrate [86]. A previous study from [87] showed that gypsum fertilization ( $132 \mathrm{~kg} \mathrm{~S} / \mathrm{ha}$ ) increased $\mathrm{S}$ from $0.33 \%$ to $0.40 \%$ and from $0.29 \%$ to $0.37 \%$ of DM in tall fescue grass and in orchadgrass, respectively. However, feeding those pastures to steers resulted in no changes in $\mathrm{Cu}$ bioavailability, probably due to the high S content of the non fertilized pastures. For this reason [73] suggest that the choice of fertilizer source can be critical in areas where grazing cattle may be prone to $\mathrm{Cu}$ deficiency Sulfur levels in drinking water can also be detrimental for $\mathrm{Cu}$ bioavailability. [88] reported a decrease in plasma and hepatic $\mathrm{Cu}$ of yearling steers provided with high-S water (3651 mg of $\mathrm{SO}_{4} / \mathrm{L}$ ) compared with those receiving low-S water (566 mg of $\mathrm{SO}_{4} / \mathrm{L}$ ). Similarly, a decrease in hepatic $\mathrm{Cu}$ of growing steers was found by [89] when $\mathrm{S}$ content in the drinking water was increased from 404 to $4654 \mathrm{mg}$ of $\mathrm{SO}_{4} / \mathrm{L}$. While the mentioned $\mathrm{S}$ concentrations are in excess of that commonly found in water for animals, high S-containing water has been reported in USA and Canada [90] [91].

\subsection{Copper-Iron Interaction}

Ruminants consuming forage-based diets are often exposed to high levels of Fe through water, forage, and unusually high amounts of soil ingestion [69] [92]. Supplementing $800 \mathrm{mg}$ of $\mathrm{Fe} / \mathrm{kg}$ of $\mathrm{DM}$ as $\mathrm{FeO}$ or $\mathrm{FeSO}_{4}$, decreased $\mathrm{Cu}$ absorption from 0.06 to 0.04 in sheep [93]. In agreement, a previous study of (94) found a rapid decrease in liver and plasma $\mathrm{Cu}$ concentrations, activities of erythrocyte superoxide dismutase and plasma ceruloplasmin of young heifers receiving $800 \mathrm{mg}$ of Fe/kg of DM. However, according to [94] the role of $\mathrm{Fe}$ on $\mathrm{Cu}$ absorption is partially dependent of S. Indeed, [81] suggest that the formation of FeS in the rumen is a critical step for Fe to antagonize $\mathrm{Cu}$ absorption. An alternative explanation is provided by [95] who demonstrate that excess Fe can compete with $\mathrm{Cu}$ for its absorption at intestinal level, by saturating the DMT-1 Cu transporter.

\subsection{Role of Copper on Rumen Fermentation}

In a production study conducted on beef steers [96], the addition of 20 or $40 \mathrm{mg}$ of $\mathrm{Cu} / \mathrm{kg}$ of DM decreased animal performance, compared with animals receiving a basal diet containing $10.2 \mathrm{mg}$ of $\mathrm{Cu} / \mathrm{kg}$ of $\mathrm{DM}$, suggesting that high dietary $\mathrm{Cu}$ may inhibit ruminal fermentation. Previously, [97] found a decrease in post feeding total VFA concentration and VFA molar proportions of yearling steers receiving a high dose of sup- 
plemented $\mathrm{Cu}(57.3 \mathrm{mg} / \mathrm{kg}$ of DM), but average daily gain, feed efficiency, and carcass yield and quality grade were not affected. In agreement, [98] found an in vitro depression in rumen fermentation of concentrates following the addition of high doses of $\mathrm{CuSO}_{4}$. Similarly, [99] found a reduction in propionate molar proportion when high doses of $\mathrm{Cu}$ were added to in vitro rumen incubations. A dose-response study conducted by [100] determined that $21 \mu \mathrm{g}$ of $\mathrm{Cu} / \mathrm{mL}$ incubation fluid was required to obtain a $50 \%$ inhibition of gas production. However, a large disparity was obtained regarding the susceptibility of the different bacterial populations to $\mathrm{Cu}$. While the growth of Bacteroides succinogenes, Ruminococcus albus and Butyrivibrio fibrisolvens was inhibited by 10,20 and $30 \mu \mathrm{g} \mathrm{Cu} / \mathrm{mL}$ of incubation fluid, respectively, higher concentrations were required to inhibit Megasphaera elsdenii, Selenomonas ruminantium, and Streptococcus bovis (100, 100 and $250 \mu \mathrm{g} \mathrm{Cu} / \mathrm{mL}$, respectively). Opposite results were reported by [101] who found a reduction in rumen $\mathrm{pH}$ and an increase in total VFA concentrations when Cashmere wether goats received supplementary $\mathrm{Cu}$ in the diet. According to the authors, an increase in NDF digestion may be responsible for these findings. Conversely, later studies conducted by [102] [103] found that NDF digestion was unchanged or maximized by the addition of $10 \mathrm{mg}$ of $\mathrm{Cu} / \mathrm{kg}$ of $\mathrm{DM}$, but depressed when of $30 \mathrm{mg}$ of $\mathrm{Cu} / \mathrm{kg}$ of DM were added. In addition, no differences were obtained for rumen $\mathrm{pH}$, IVDMD and VFA molar proportions when in vitro studies were conducted using rumen fluid donors receiving 0,10 or $20 \mathrm{mg}$ of $\mathrm{Cu} / \mathrm{kg}$ of DM [104]. Based on previous observations showing that 20 or $40 \mathrm{mg}$ of $\mathrm{Cu} / \mathrm{kg}$ of DM increased unsaturated fatty acids in adipose tissue of steers [104], a possible role of $\mathrm{Cu}$ as an inhibitor of ruminal lipids biohydrogenation has been suggested. [105] However, no studies have been conducted to assess the validity of this hypothesis.

\subsection{Copper Availability from Organic and Inorganic Sources}

The effectiveness of organic sources of $\mathrm{Cu}$ to promote animal benefits has been a subject of several controversies. [106] reported a higher retention of $\mathrm{Cu}$ in steers supplemented with $\mathrm{Cu}$-lysine compared with supplementation with $\mathrm{CuSO}_{4}$. In another study [107], the use of organic $\mathrm{Cu}$ (as $\mathrm{Cu}$ proteinate) increased hepatic retention of $\mathrm{Cu}$ in multiparous beef cows, compared with inorganic $\mathrm{Cu}$. However, no benefits on cow and calf performance were obtained. Conversely, [108] found an increase in body weight gain in goat kids supplemented with organic $\mathrm{Cu}$, compared with inorganic $\mathrm{Cu}$. In a recent meta-analysis [13] assessing the benefits of organic trace minerals, only marginal improvements in milk production, milk fat and milk protein were found. In opposition, organic trace minerals did not affect somatic cell count, interval from calving to first service, and 21-d pregnancy rate. Similarly, no differences in 60-d pregnancy rate, health or performance were found by [109] in 2-year old cows receiving $\mathrm{Cu}$ as $\mathrm{CuSO}_{4}$ or as amino acid complex. In addition, [110] found a decrease in pregnancy rates of primiparous cows receiving organic and inorganic minerals $(\mathrm{Cu}, \mathrm{Co}, \mathrm{Mn}$ and $\mathrm{Zn}$ ) compared with non-supplemented cows. According to the authors, excessive supplementation beyond requirements reduced reproductive performance. In a previous 
study conducted on steers [71], growth rate was higher when animals received $\mathrm{CuSO}_{4}$ than when $\mathrm{Cu}$-lysine was provided during the initial $21 \mathrm{~d}$, but no differences were obtained after $98 \mathrm{~d}$. Other parameters, including feed efficiency, feed intake, humoral and cellular immune response and ceruloplasmin activity, were not affected by $\mathrm{Cu}$ source [71]. Organic sources of $\mathrm{Cu}$ have been seriously criticized by [8] who consider that technologies for protection against rumen antagonisms are extravagant and provide no additional benefits than conventional $\mathrm{CuSO}_{4}$. In addition the authors questioned the scientific legitimacy of some in vivo studies where no proper covariance analyses were conducted to account for initial differences between groups of animals [8]. According to [9] commercially driven pursuit of trivial advantages over cheap and effective inorganic sources of $\mathrm{Cu}$ should cease, and attention should focused on predicting when supplementation is needed and to the usual problem of over, rather than under-provision of $\mathrm{Cu}$ and its environmental impact. In conclusion, $\mathrm{Cu}, \mathrm{Zn}$ and $\mathrm{Mn}$ are required to maintain health and production status of livestock, but their functions at the gastrointestinal tract of ruminants are not totally elucidated. Like many other minerals, $\mathrm{Cu}, \mathrm{Zn}$ and $\mathrm{Mn}$ have the ability to interact with organic compounds of the diet, macro minerals and micro minerals, usually resulting in decreased availability for the host. Different technologies, including proteinates, amino acid chelates, amino acid complex, and polysaccharide complex are currently available for mineral protection However, these technologies appear to be more effective in monogastrics than in ruminants. Mechanisms to guarantee optimal levels of ruminally available minerals, and to optimize mineral supply to the lower gastrointestinal tract without compromising postruminal absorption require further research.

\section{Trace Minerals $\mathrm{Cu}, \mathrm{Zn}, \mathrm{Mn}$ and Their Effect on Immune Function}

Trace minerals are those needed by the body in minute amounts (generally included in the diet in parts per million quantities). Several of these trace minerals such as zinc, manganese, copper, and cobalt are required for the functionality of numerous structural proteins, enzymes, and cellular proteins [35]. Trace minerals may function as cofactors, activators of enzymes, or stabilizers of secondary molecular structure and serve essential functions in cell metabolism [111]. Numerous studies have shown that feeding amino acid complexes of $\mathrm{Zn}, \mathrm{Mn}$, and $\mathrm{Cu}$ have improved the performance of dairy cattle through improving fertility rates and reducing the incidence of disease [112] [113] [114]. These improvements in animal performance appear to be related to increased availability of trace minerals for metabolism [115] [116].

Ruminants are frequently subjected to severe dietary deficiencies of trace elements such as copper, cobalt, selenium, iodine, manganese, and zinc [37]. These deficiencies have been linked to a decline in fertility from enzymatic dysfunctions. Hypocuprosis in dairy cattle and sheep has been linked to female reproductive disorders such as prevention of embryo implantation and high prenatal mortality, particularly early embryonic loss [37]. Several studies in rats and mice have shown that both cell-mediated and hu- 
moral immunity are greatly depressed by copper deficiency [37] [117]. [118] showed that marginal copper deficiency in dairy heifers reduced the capacity of neutrophils to kill S. aureus. Animals deficient in copper also show an increased susceptibility to bacterial pathogens. This has been attributed to the role of copper in superoxide dismutase and cytochrome c oxidase enzyme systems [119]. [4] reported that copper deficiency impaired the ability of macrophages to kill yeast cells. [120] demonstrated that copper-depleted calves exhibited impaired phagocytic killing activity that was reversed by copper supplementation. In another study, low copper status was associated with a reduced response of peripheral-blood lymphocytes to stimulation with T-cell mitogens [121]. Despite these studies, the overall effect of copper deficiency on macrophage function in cattle has not been studied extensively [122].

Extensive research conducted on human subjects and laboratory animals suggests that zinc deficiency reduces immune responses and disease resistance [123]. In children, zinc deficiency has been shown to affect T-lymphocyte and neutrophil function along with reduced proliferation of lymphocytes in the presence of mitogens and slower neutrophil chemotaxis [119]. Zinc deficiency also produces atrophy of the lymphoid tissues such as the thymus. Zinc deficiency also negatively impacts phagocyte function resulting in decreased ingestion and phagocytosis [124]. A study conducted in laboratory animals fed a moderately zinc deficient diet showed that the differentiation and function of B-cells may be impaired [125]. In cattle, surprisingly little research has been conducted to examine the relationship between dietary zinc and immune function. Marginal zinc deficiency appears to have marginal effects on immune function in ruminants, but research also suggests that the addition of zinc to practical diets may affect disease resistance [22]. Zinc deficiency is most deleterious to the reproductive function of male animals; however, the administration of a zinc supplement to cattle was shown to increase conception rate by $23 \%$ compared to controls, and discontinuation of this supplement resulted in decreased conception rate [126].

Manganese deficiency has been linked to suppression of estrus, reduction in conception rates, increased incidence of abortions, and low birth weights. In dairy cattle, the main clinical sign of restricted manganese intake is anestrus or irregular return to estrus sometimes with extended periods of anestrus [127]. This leads to depressed conception rates [37]. Experimental animals fed a manganese deficient diet have been shown to have deficient antibody synthesis and secretion [128]. After adding manganese to the diet, antibody production improved. The mechanism(s) by which manganese affects antibody synthesis or release has not been clearly elucidated and further study in this area is needed [128].

\section{Conclusions}

In this review paper, we conclude the following:

1) Trace elements are essential for health, growth, production and reproduction. They are essential for functioning of a number of components of the immune system. Thus, they contribute to maintaining proper health and immunity. They are important 
for functioning of a number of enzymes and proteins which are involved in many physiological and biochemical processes.

2) Essential trace minerals such as zinc, copper and manganese play a wide variety of biological and physiological roles in animal development and health. These minerals take part in the antioxidant defense, tissue development, and immune function.

3) There is almost a consensus that organic trace minerals have higher bioavailability, resulting in better animal performance, health, production immune response and stress alleviation than their inorganic salts.

4) Quantifying the requirements for trace minerals of dairy cows is extremely difficult and the methods and models currently used may not be appropriate because of the different metabolic functions of trace minerals. There is also lack of proper acts and regulations for monitoring their quality for commercial marketing.

\section{References}

[1] NRC (2001) Nutrient Requirements for Dairy Cattle. 7th Revised Edition, National Academy Press, Washington DC.

[2] Underwood, E.J. (1981) The Mineral Nutrition of Livestock. 2nd Edition, Commonwealth Agricultural Bureaux, Slough.

[3] Smart, M.E., Gudmundson, J. and Christensen, D.A. (1981) Trace Mineral Deficiencies in Cattle: A Review. Canadian Veterinary Journal, 22, 372-376.

[4] Babu, U. and Faila, M.L. (1990) Respiratory Burst and Candidacidal Activity or Peritoneal Macrophages Are Impaired in Copper-Deficient Rats. Journal of Nutrition, 120, 1692-1697.

[5] Saker, K. (2006) Nutrition and Immune Function. Veterinary Clinics of North America: Small Animal Practice, 36, 1199-1224. http://dx.doi.org/10.1016/j.cvsm.2006.09.001

[6] Karol, P.J., Nakahara, H., Petley, B.W. and Vogt, E. (2003) On the Claims for Discovery of Elements 110, 111, 112, 114, 116, and 118. Pure and Applied Chemistry, 75, 1601-1611. http://dx.doi.org/10.1351/pac200375101601

[7] Wolfe-Simon, F., Blum, J.S., Kulp, T.R., Gordonm G.W., Hoeft S.E., Pett-Ridge, J., Stolz J.F., Webb, S.M., Weber, P.K., Davies, P.C.W., Anbar, A.D. and Oremland, R.S. (2010) A Bacterium That Can Grow by Using Arsenic Instead of Phosphorus. Science, 332, 1163 1166. http://dx.doi.org/10.1126/science. 1197258

[8] Underwood, E.J. and Suttle, N. (2001) The Mineral Nutrition of Livestock. 3rd Edition, CABI Publishing, Wallingford.

[9] Suttle, N.F. (2010) Mineral Nutrition of Livestock. 4th Edition, CABI, Cambridge. http://dx.doi.org/10.1079/9781845934729.0000

[10] Spears, J.W. (2002) Overview of Mineral Nutrition in Cattle: The Dairy and Beef NRC. 13th Annual Florida Ruminant Nutrition Symposium, University of Florida, Gainesville, 113126.

[11] Ammerman, C.B. (1995) Methods for Estimation of Mineral Bioavailability. In: Ammerman, C.B., Baker, D.H. and Lewis, A.J., Eds., Bioavailability of Nutrients for Animals. Amino Acids, Minerals, and Vitamins, Academic Press, Pittsburgh, 83-94. http://dx.doi.org/10.1016/B978-012056250-3/50031-7

[12] Hazell, T. (1985) Minerals in Foods: Dietary Sources, Chemical Forms, Interactions, Bioavailability. World Review of Nutrition and Dietetics, 46, 1-123.

http://dx.doi.org/10.1159/000411649 
[13] Rabiee, A.R., Lean, I.J., Stevenson, M.A. and Socha, M.T. (2010) Effects of Feeding Organic Trace Minerals on Milk Production and Reproductive Performance in Lactating Dairy Cows: A Meta-Analysis. Journal of Dairy Science, 93, 4239-4251. http://dx.doi.org/10.3168/jds.2010-3058

[14] AAFCO (2000) Official Publication-Association of American Feed Control Officials. Atlanta.

[15] Roy, R.K. and Misger, F.A. (2008) Chelated Minerals in Livestock Nutrition: A Review. Environment and Ecology, 26, 665-668.

[16] Hynes, M.J. and Kelly, M.P. (1995) Metal Ions, Chelates and Proteinates. In: Lyons, T.P. and Jacques, K.A., Eds., Biotechnology in the Feed Industry, Nottingham University Press, Nottingham, 233-248.

[17] Miller, W.J. (1970) Zinc Nutrition of Cattle: A Review. Journal of Dairy Science, 53, 11231135. http://dx.doi.org/10.3168/jds.S0022-0302(70)86355-X

[18] Ansari, M.S., Miller, W.J., Neathery, M.W., Lassiter, J.W., Gentry, R.P. and Kincaid, R.L. (1976) Zinc Metabolism and Homeostasis in Rats Fed a Wide Range of High Dietary Zinc Levels. Proceedings of the Society for Experimental Biology and Medicine, 152, 192-194. http://dx.doi.org/10.3181/00379727-152-39358

[19] Chu, G.M., Komori, M., Hattori, R. and Matsui, T. (2009) Dietary Phytase Increases the True Absorption and Endogenous Fecal Excretion of Zinc in Growing Pigs Given a Corn-Soybean Meal Based Diet. Animal Science Journal, 80, 46-51. http://dx.doi.org/10.1111/j.1740-0929.2008.00595.x

[20] Spears, J.W. (2003) Trace Mineral Bioavailability in Ruminants. Journal of Nutrition, 133, 1506S-1509S.

[21] Baker, D.H. and Ammerman, C.B. (1995) Zinc Bioavailability. In: Ammerman, C.B., Baker, D.H. and Lewis, A.J., Eds., Bioavailability of Nutrients for Animals. Amino Acids, Minerals, and Vitamins, Academic Press, San Diego, 367-398. http://dx.doi.org/10.1016/B978-012056250-3/50044-5

[22] Sonawane, S.N. and Arora, S.P. (1976) Influence of Zinc Supplementation on Rumen Microbial Protein Synthesis in in Vitro Studies. Indian Journal of Animal Sciences, 46, 13-18.

[23] Bonhomme, A., Durand, M., Dumay, C. and Beaumatin, P. (1979) Etude in Vitro du comportement des populations microbiennes du rumen en présence de zinc sous forme de sulfate. Annales de Biologie Animale, Biochimie, Biophysique, 19, 937-942. http://dx.doi.org/10.1051/rnd:19790634

[24] Martinez, A. and Church, D.C. (1970) Effect of Various Mineral Elements on in Vitro Rumen Cellulose Digestion. Journal of Animal Science, 31, 982-990. http://dx.doi.org/10.2527/jas1970.315982x

[25] Arelovich, H.M., Owens, F.N., Horn, G.W. and Vizcarra, J.A. (2000) Effects of Supplemental Zinc and Manganese on Ruminal Fermentation, Forage Intake, and Digestion by Cattle Fed Prairie Hay and Urea. Journal of Animal Science, 78, 2972-2979. http://dx.doi.org/10.2527/2000.78112972x

[26] Spears, J.W., Schlegel, P., Seal, M.C. and Lloyd, K.E. (2004) Bioavailability of Zinc from Zinc Sulfate and Different Organic Zinc Sources and Their Effects on Ruminal Volatile Fatty Acid Proportions. Livestock Production Science, 90, 211-217. http://dx.doi.org/10.1016/j.livprodsci.2004.05.001

[27] Eryavuz, A. and Dehority, B.A. (2009) Effects of Supplemental Zinc Concentration on Cellulose Digestion and Cellulolytic and Total Bacterial Numbers in Vitro. Animal Feed Science and Technology, 151, 175-183. http://dx.doi.org/10.1016/j.anifeedsci.2009.01.008 
[28] Bonhomme, A. (1990) Rumen Ciliates: Their Metabolism and Relationships with Bacteria and Their Hosts. Animal Feed Science and Technology, 30, 203-266.

http://dx.doi.org/10.1016/0377-8401(90)90016-2

[29] Pell, A. and Schofield, P. (1993) Microbial Adhesion and Degradation of Plant Cell Walls. Forage Cell Wall Struct. Dig. ACS, Ithaca, 397-423.

[30] Spears, J.W. (1989) Zinc Methionine for Ruminants: Relative Bioavailability of Zinc in Lambs and Effects of Growth and Performance of Growing Heifers. Journal of Animal Science, 67, 835-843. http://dx.doi.org/10.2527/jas1989.673835x

[31] Mandal, G.P., Dass, R.S., Varshney, V.P. and Mondal, A.B. (2008) Effect of Zinc Supplementation from Inorganic and Organic Sources on Growth and Blood Biochemical Profile in Crossbred Calves. Journal of Animal and Feed Sciences, 17, 147-156.

[32] Dorton, K.L., Wagner, J.J., Larson, C.K., Enns, R.M. and Engle, T.E. (2010) Effects of Trace Mineral Source and Growth Implants on Trace Mineral Status of Growing and Finishing Feedlot Steers. Asian-Australasian Journal of Animal Sciences, 23, 907-915. http://dx.doi.org/10.5713/ajas.2010.90414

[33] Huerta, M., Kincaid, R.L., Cronrath, J.D., Busboom, J., Johnson, A.B. and Swenson, C.K. (2002) Interaction of Dietary Zinc and Growth Implants on Weight Gain, Carcass Traits and Zinc in Tissues of Growing Beef Steers and Heifers. Animal Feed Science and Technology, 95, 15-32. http://dx.doi.org/10.1016/S0377-8401(01)00334-0

[34] Siciliano-Jones, J.L., Socha, M.T., Tomlinson, D.J. and DeFrain, J.M. (2008) Effect of Trace Mineral Source on Lactation Performance, Claw Integrity, and Fertility of Dairy Cattle. Journal of Dairy Science, 91, 1985-1995. http://dx.doi.org/10.3168/jds.2007-0779

[35] Nocek, J.E., Socha, M.T. and Tomlinson, D.J. (2006) The Effect of Trace Mineral Fortification Level and Source on Performance of Dairy Cattle. Journal of Dairy Science, 89, 26792693. http://dx.doi.org/10.3168/jds.S0022-0302(06)72344-X

[36] Suttle, N.F., Davies, H.L. and Field, A.C. (1982) A Model for Zinc Metabolism in Sheep Given a Diet of Hay. British Journal of Nutrition, 47, 105-112. http://dx.doi.org/10.1079/BJN19820015

[37] Howes, A.D. and Dyer, I.A. (1971) Diet and Supplemental Mineral Effects on Manganese Metabolism in Newborn Calves. Journal of Animal Science, 32, 141-145. http://dx.doi.org/10.2527/jas1971.321141x

[38] Atkinson, S., Shah, J., Webber, C., Gibson, I. and Gibson, R. (1993) A Multi-Element Isotopic Tracer Assessment of True Fractional Absorption of Minerals from Formula with Additives of Calcium, Phosphorus, Zinc, Copper and Iron in Young Piglets. Journal of $\mathrm{Nu}$ trition, 123, 1586-1593.

[39] Sansom, B.F., Symonds, H.W. and Vagg, M.J. (1978) The Absorption of Dietary Manganese by Dairy Cows. Research in Veterinary Science, 24, 366-369.

[40] Henry, P., Ammerman, C. and Miles, R. (1986) Influence of Virginiamycin and Dietary Manganese on Performance, Manganese Utilization, and Intestinal Tract Weight of Broilers. Poultry Science, 65, 321-324. http://dx.doi.org/10.3382/ps.0650321

[41] Henry, P.R., Ammerman, C.B. and Littell, R.C. (1992) Relative Bioavailability of Manganese from a Manganese-Methionine Complex and Inorganic Sources for Ruminants. Journal of Dairy Science, 75, 3473-3478. http://dx.doi.org/10.3168/jds.S0022-0302(92)78123-5

[42] Salinas-Chavira, J., Lenin, J., Ponce, E., Sanchez, U., Torrentera, N. and Zinn, R.A. (2009) Comparative Effects of Virginiamycin Supplementation on Characteristics of Growth-Performance, Dietary Energetics, and Digestion of Calf-Fed Holstein Steers. Journal of Animal Science, 87, 4101-4108. http://dx.doi.org/10.2527/jas.2009-1959 
[43] Hidiroglou, M. (1979) Manganese in Ruminant Nutrition. Canadian Journal of Animal Science, 59, 217-236. http://dx.doi.org/10.4141/cjas79-028

[44] Baker, D. and Oduho, G. (1994) Manganese Utilization in the Chick: Effects of Excess Phosphorus on Chicks Fed Manganese-Deficient Diets. Poultry Science, 73, 1162-1165. http://dx.doi.org/10.3382/ps.0731162

[45] Wedekind, K.J., Titgemeyer, E.C., Twardock, A.R. and Baker, D.H. (1991) Phosphorus, but Not Calcium, Affects Manganese Absorption and Turnover in Chicks. Journal of Nutrition, 121, 1776-1786.

[46] Davidsson, L., Almgren, A.M. and Hurrell, R. (1995) Manganese Absorption in Humans: The Effect of Phytic Acid and Ascorbic Acid in Soy Formula. American Journal of Clinical Nutrition, 62, 984-987.

[47] Richards, J., Zhao, J., Harrell, R., Atwell, C. and Dibner, J. (2010) Trace Mineral Nutrition in Poultry and Swine. Asian-Australasian Journal of Animal Sciences, 23, 1527-1534. http://dx.doi.org/10.5713/ajas.2010.r.07

[48] Yanke, L., Bae, H., Selinger, L. and Cheng, K. (1998) Phytase Activity of Anaerobic Ruminal Bacteria. Microbiology, 144, 1565-1573. http://dx.doi.org/10.1099/00221287-144-6-1565

[49] Spears, J.W. and Hatfield, E.E. (1978) Nickel for Ruminants. I. Influence of Dietary Nickel on Ruminal Urease Activity. Journal of Animal Science, 47, 1345-1350. http://dx.doi.org/10.2527/jas1978.4761345x

[50] Chamberlain, C.C. and Burroughs, W. (1962) Effect of Fluoride, Magnesium and Manganese Ions on in Vitro Cellulose Digestion by Rumen Microorganisms. Journal of Animal Science, 21, 428-432. http://dx.doi.org/10.2527/jas1962.213428x

[51] Ivan, M. (1979) Metabolism of Radiomanganese and Radiozinc in Sheep-Effects of Intraruminal Dosing with Nitrilotriacetic Acid. Canadian Journal of Animal Science, 59, 283 289. http://dx.doi.org/10.4141/cjas79-034

[52] Ivan, M. (1981) Distribution of Radiomanganese in the Rumen of Sheep. Canadian Journal of Physiology and Pharmacology, 59, 76-83. http://dx.doi.org/10.1139/y81-013

[53] Masters, D.G., Paynter, D.I., Briegel, J., Baker, S.K. and Purser, D.B. (1988) Influence of Manganese Intake on Body, Wool and Testicular Growth of Young Rams and on the Concentration of Manganese and the Activity of Manganese Enzymes in Tissues. Australian Journal of Agricultural Research, 39, 517-524. http://dx.doi.org/10.1071/AR9880517

[54] Czerkawski, J.W. (1976) Chemical Composition of Microbial Matter in the Rumen. Journal of the Science of Food and Agriculture, 27, 621-632. http://dx.doi.org/10.1002/jsfa.2740270707

[55] Panggabean, T., Moir, R., Purser, D. and Laby, R. (1984) Multi-Element Effects in Sheep. Proceedings of a Symposium on Ruminant Physiology, Concepts and Consequences, University of Western Australia, Perth, 7-10 May 1984, 347-355.

[56] Durand, M. and Kawashima, R. (1980) Influence of Minerals in Rumen Microbial Digestion. In: Ruckebusch, Y. and Thivend, P., Eds., Digestive Physiology and Metabolism in Ruminants, MTP Press Ltd., Lancaster, 375-408. http://dx.doi.org/10.1007/978-94-011-8067-2_18

[57] Forbes, R. and Erdman, J.W. (1983) Bioavailability of Trace Mineral Elements. Annual Review of Nutrition, 3, 213-231. http://dx.doi.org/10.1146/annurev.nu.03.070183.001241

[58] Ammerman, C. and Miller, S. (1972) Biological Availability of Minor Mineral Ions: A Review. Journal of Animal Science, 35, 681-694. http://dx.doi.org/10.2527/jas1972.353681x

[59] Wong-Valle, J., Henry, P., Ammerman, C. and Rao, P. (1989) Estimation of the Relative 
Bioavailability of Manganese Sources for Sheep. Journal of Animal Science, 67, 2409-2414. http://dx.doi.org/10.2527/jas1989.6792409x

[60] McDowell, L. (1992) Minerals in Animal and Human Nutrition. Academic Press Inc., San Diego.

[61] DiCostanzo, A., Meiske, J., Plegge, S., Haggard, D. and Chaloner, K. (1986) Influence of Manganese, Copper and Zinc on Reproductive Performance of Beef Cows. Nutrition Reports International, 34, 287-292.

[62] Scheideler, S. (1991) Interaction of Dietary Calcium, Manganese, and Manganese Source (Mn Oxide or Mn Methionine Complex) on Chick Performance and Manganese Utilization. Biological Trace Element Research, 29, 217-228. http://dx.doi.org/10.1007/BF03032679

[63] Smith, M., Sherman, I., Miller, L., Robbins, K. and Halley, J. (1995) Relative Biological Availability of Manganese from Manganese Proteinate, Manganese Sulfate, and Manganese Monoxide in Broilers Reared at Elevated Temperatures. Poultry Science, 74, 702-707. http://dx.doi.org/10.3382/ps.0740702

[64] Spears, J.W. and Hansen, S.L. (2008) Bioavailability Criteria for Trace Minerals in Monogastrics and Ruminants. Academic Publishers, Wageningen, 161-175.

[65] Kratzer, F.H. (1986) Chelates in Nutrition. CRC Press, Boca Raton.

[66] Li, S.F., Luo, X.G., Lu, L., Crenshaw, T.D., Bu, Y.Q., Liu, B., Kuang, X., Shao G.Z. and Yu, S. X. (2005) Bioavailability of Organic Manganese Sources in Broilers Fed High Dietary Calcium. Animal Feed Science and Technology, 123-124, 703-715. http://dx.doi.org/10.1016/j.anifeedsci.2005.04.052

[67] Fly, A.D., Izquierdo, O.A., Lowry, K.R. and Baker, D.H. (1989) Manganese Bioavailability in a Mn-Methionine Chelate. Nutrition Research, 9, 901-910. http://dx.doi.org/10.1016/S0271-5317(89)80035-1

[68] Linder, M.C. (2002) Biochemistry and Molecular Biology of Copper in Mammals. In: Massaro, E.J., Ed., Handbook of Copper Pharmacology and Toxicology, Humana Press Inc., Totowa, 3-32. http://dx.doi.org/10.1385/1-59259-288-0:003

[69] Suttle, N.F., Alloway, B.J. and Thornton, I. (1975) Effect of Soil Ingestion on the Utilization of Dietary Copper by Sheep. Journal of Agricultural Science, 84, 249-254. http://dx.doi.org/10.1017/S0021859600052369

[70] Dick, A.T. (1953) The Control of Copper Storage in the Liver of Sheep by Inorganic Sulphate and Molybdenum. Australian Veterinary Journal, 29, 233-239. http://dx.doi.org/10.1111/j.1751-0813.1953.tb08142.x

[71] Ward, J.D., Spears, J.W. and Kegley, E.B. (1993) Effect of Copper Level and Source (Copper Lysine vs Copper Sulfate) on Copper Status, Performance, and Immune Response in Growing Steers fed Diets with or without Supplemental Molybdenum and Sulfur. Journal of Animal Science, 71, 2748-2755.

[72] Suttle, N.F. (1974) Effects of Organic and Inorganic Sulphur on the Availability of Dietary Copper to Sheep. British Journal of Nutrition, 32, 559-568. http://dx.doi.org/10.1079/BJN19740109

[73] Arthington, J.D. and Pate, F.M. (2002) Effect of Corn- vs Molasses-Based Supplements on Trace Mineral Status in Beef Heifers. Journal of Animal Science, 80, 2787-2791. http://dx.doi.org/10.2527/2002.80112787x

[74] Jarvis, S.C. and Austin, A.R. (1983) Soil and Plant Factors Limiting the Availability of Copper to a Beef Suckler Herd. Journal of Agricultural Science, 101, 9-46. http://dx.doi.org/10.1017/S0021859600036340 
[75] Mackenzie, A.M., Edwards, C.L. and Wilkinson, R.G. (1983) The Effect of Dietary Molybdenum or Iron on Copper Status and Ceruloplasmin Expression in Sheep. Academic Publishers, Wageningen, 281-283.

[76] Legleiter, L.R. and Spears, J.W. (2007) Plasma Diamine Oxidase: A Biomarker of Copper Deficiency in the Bovine. Journal of Animal Science, 85, 2198-2204.

http://dx.doi.org/10.2527/jas.2006-841

[77] Hansen, S.L., Ashwell, M.S., Legleiter, L.R., Fry, R.S., Lloyd, K.E. and Spears, J.W. (2009) The Addition of High Manganese to a Copper-Deficient Diet Further Depresses Copper Status and Growth of Cattle. British Journal of Nutrition, 101, 1068-1078. http://dx.doi.org/10.1017/S0007114508057589

[78] Mason, J. (1986) Thiomolybdates: Mediators of Molybdenum Toxicity and Enzyme Inhibitors. Toxicology, 42, 99-109. http://dx.doi.org/10.1016/0300-483X(86)90001-6

[79] Allen, J.D. and Gawthorne, J.M. (1987) Involvement of the Solid Phase of Rumen Digesta in the Interaction between Copper, Molybdenum and Sulfur in Sheep. British Journal of $\mathrm{Nu}$ trition, 58, 265-276. http://dx.doi.org/10.1079/BJN19870094

[80] Suttle, N.F. (1991) The Interactions between Copper, Molybdenum, and Sulphur in Ruminant Nutrition. Annual Review of Nutrition, 11, 121-140. http://dx.doi.org/10.1146/annurev.nu.11.070191.001005

[81] Suttle, N.F. (1975) Changes in the Availability of Dietary Copper to Young Lambs Associated with Age and Weaning. Journal of Agricultural Science, 84, 255-261. http://dx.doi.org/10.1017/S0021859600052370

[82] Van Ryssen, J.B.J., Van Malsen, P.S.M. and Hartmann, F. (1998) Contribution of Dietary Sulfur to the Interaction between Selenium and Copper in Sheep. Journal of Agricultural Science, 130, 107-114. http://dx.doi.org/10.1017/S0021859697005030

[83] Jouany, J.P. (1991) Rumen Microbial Metabolism and Ruminant Digestion. INRA.

[84] Morales, J.L., Van Horn, H.H. and Moore, J.E. (1989) Dietary Interaction of Cane Molasses with Source of Roughage: Intake and Lactation Effects. Journal of Dairy Science, 72, 23312338. http://dx.doi.org/10.3168/jds.S0022-0302(89)79365-6

[85] Zinn, R.A., Alvarez, E., Mendez, M., Montano, M., Ramirez, E. and Shen, Y. (1997) Influence of Dietary Sulfur Level on Growth Performance and Digestive Function in Feedlot Cattle. Journal of Animal Science, 75, 1723-1728. http://dx.doi.org/10.2527/1997.7571723x

[86] Arthington, J.D. (2003) Copper Antagonists in Cattle Nutrition. 14th Annual Florida Ruminant Nutrition Symposium, Gainesville, 16-17 January 2003, 48.

[87] Spears, J.W., Burns, J.C. and Hatch, P. (1985) Sulfur Fertilization of Cool Season Grasses and Effect on Utilization of Minerals, Nitrogen, and Fiber by Steers. Journal of Dairy Science, 68, 347-355. http://dx.doi.org/10.3168/jds.S0022-0302(85)80831-6

[88] Cammack, K.M., Wright, C.L., Austin, K.J., Johnson, P.S., Cockrum, R.R., Kessler, K.L. and Olson, K.C. (2010) Effects of High-Sulfur Water and Clinoptilolite on Health and Growth Performance of Steers Fed Forage-Based Diets. Journal of Animal Science, 88, 1777-1785. http://dx.doi.org/10.2527/jas.2009-2343

[89] Wright, C.L. and Patterson, H.H. (2006) Effect of High-Sulfate Water on Trace Mineral Status of Beef Steers. Journal of Animal Science, 84, 228.

[90] Paterson, J.A., Swenson, C.K., Johnson, A.B. and Asotegui, R.P. (1999) Life Cycle Trace Mineral Needs for Reducing Stress in Beef Production. 60 th Minnesota Nutrition Conference, Bloomington, 20-22 September 1999, 41.

[91] Haydock, D. (2003) Sulfur-Induced Polioencephalomalacia in a Herd of Rotationally 
Grazed Beef Cattle. Canadian Veterinary Journal, 44, 828-829.

[92] Mullis, L.A., Spears, J.W. and McCraw, R.L. (2003) Effects of Breed (Angus vs Simmental) and Copper and Zinc Source on Mineral Status of Steers Fed High Dietary Iron. Journal of Animal Science, 81, 318-322. http://dx.doi.org/10.2527/2003.811318x

[93] Suttle, N.F. and Peter, D.W. (1985) Rumen Sulfide Metabolism as a Major Determinant of Copper Availability in the Diets of Sheep. Proceedings of 5 th International Symposium on Trace Elements in Man and Animals, Aberdeen, 367-370.

[94] Humphries, W.R., Phillippo, M., Young, B.W. and Bremner, I. (1983) The Influence of Dietary Iron and Molybdenum on Copper Metabolism in Calves. British Journal of Nutrition, 49, 77-86. http://dx.doi.org/10.1079/BJN19830013

[95] Arredondo, M., Muñoz, P., Mura, C.V. and Núñez, M.T. (2003) DMT1, a Physiologically Relevant Apical $\mathrm{Cu}^{1+}$ Transporter of Intestinal Cells. American Journal of Physiology-Cell Physiology, 284, C1525-C1530. http://dx.doi.org/10.1152/ajpcell.00480.2002

[96] Engle, T.E. and Spears, J.W. (2000) Effects of Dietary Copper Concentration and Source on Performance and Copper Status of Growing and Finishing Steers. Journal of Animal Science, 78, 2446-2451. http://dx.doi.org/10.2527/2000.7892446x

[97] Essig, H.W., Davis, J.D. and Smithson, L.J. (1972) Copper Sulfate in Steer Rations. Journal of Animal Science, 35, 436-439. http://dx.doi.org/10.2527/jas1972.352436x

[98] Slyter, L.L. and Wolin, M.J. (1967) Copper Sulfate-Induced Fermentation Changes in Continuous Cultures of the Rumen Microbial Ecosystem. Applied Microbiology, 15, 1160-1164.

[99] Piva, G., Masoero, F. and Prandini, A. (1986) The Effects of Paraformaldehyde and of Zinc, Copper and Iron Salts on Ruminal Fermentation: In Vitro Trials. Microbiologie, Aliments, Nutrition, 4, 117-120.

[100] Forsberg, C.W. (1978) Effects of Heavy Metals and Other Trace Elements on the Fermentative Activity of the Rumen Microflora and Growth of Functionally Important Rumen Bacteria. Canadian Journal of Microbiology, 24, 298-306. http://dx.doi.org/10.1139/m78-050

[101] Zhang, W., Wang, R., Zhu, X., Kleemann, D.O., Yue, C. and Jia, Z. (2007) Effects of Dietary Copper on Ruminal Fermentation, Nutrient Digestibility and Fibre Characteristics in Cashmere Goats. Asian-Australasian Journal of Animal Sciences, 20, 1843-1848. http://dx.doi.org/10.5713/ajas.2007.1843

[102] Zhang, W., Wang, R., Kleemann, D.O., Lu, D., Zhu, X., Zhang, C. and Jia, Z. (2008) Effects of Dietary Copper on Nutrient Digestibility, Growth Performance and Plasma Copper Status in Cashmere Goats. Small Ruminant Research, 74, 188-193. http://dx.doi.org/10.1016/j.smallrumres.2007.06.010

[103] Zhang, W., Wang, R., Kleemann, D.O., Gao, M., Xu, J. and Jia, Z. (2009) Effects of Dietary Copper on growth Performance, Nutrient Digestibility and Fiber Characteristics in Cashmere goats during the Cashmere Slow-Growing Period. Small Ruminant Research, 85, 5862. http://dx.doi.org/10.1016/j.smallrumres.2009.07.006

[104] Engle, T.E. and Spears, J.W. (2000) Dietary Copper Effects on Lipid Metabolism, Performance, and Ruminal Fermentation in Finishing Steers. Journal of Animal Science, 78, 2452-2458. http://dx.doi.org/10.2527/2000.7892452x

[105] Engle, T.E. (2011) Copper and Lipid Metabolism in Beef Cattle: A Review. Journal of Animal Science, 89, 591-596. http://dx.doi.org/10.2527/jas.2010-3395

[106] Nockels, C.F., DeBonis, J. and Torrent, J. (1993) Stress Induction Affects Copper and Zinc Balance in Calves Fed Organic and Inorganic Copper and Zinc Sources. Journal of Animal Science, 71, 2539-2545. 
[107] Ahola, J.K., Baker, D.S., Burns, P.D., Mortimer, R.G., Enns, R.M., Whittier, J.C., Geary, W. and Engle, T.E. (2004) Effect of Copper, Zinc, and Manganese Supplementation and Source on Reproduction, Mineral Status, and Performance in Grazing Beef Cattle over a Two-Year Period. Journal of Animal Science, 82, 2375-2383. http://dx.doi.org/10.2527/2004.8282375x

[108] Datta, C., Mondal, M.K. and Biswas, P. (2007) Influence of Dietary Inorganic and Organic Form of Copper Salt on Performance, Plasma Lipids and Nutrient Utilization of Black Bengal (Capra hircus) Goat Kids. Animal Feed Science and Technology, 135, 191-209. http://dx.doi.org/10.1016/j.anifeedsci.2006.06.008

[109] Muehlenbein, E.L., Brink, D.R., Deutscher, G.H., Carlson, M.P. and Johnson, A.B. (2001) Effects of Inorganic and Organic Copper Supplemented to First-Calf Cows on Cow Reproduction and Calf Health and Performance. Journal of Animal Science, 79, 1650-1659. http://dx.doi.org/10.2527/2001.7971650x

[110] Olson, P.A., Brink, D.R. Hickok, D.T., Carlson, M.P., Schneider, N.R., Deutscher, G.H., Adams, D.C., Colburn, D.J. and Johnson, A.B. (1999) Effects of Supplementation of Organic and Inorganic Combinations of Copper, Cobalt, Manganese, and Zinc Above Nutrient Requirement Levels on Postpartum Two-Year-Old Cows. Journal of Animal Science, 77, 522-532. http://dx.doi.org/10.2527/1999.773522x

[111] Valee, B.L. and Wacker, W.E.C. (1976) The Proteins. Neurath, H., Ed., Vol. 5, Academic Press, New York.

[112] Kellogg, D.W., Tomlinson, D.J., Socha, M.T. and Johnson, A.B. (2004) Review: Effects of Zinc Methionine Complex on Milk Production and Somatic Cell Count of Dairy Cows: Twelve Trial Summary. Professional Animal Scientist, 20, 295-301. http://dx.doi.org/10.15232/S1080-7446(15)31318-8

[113] Nocek, J.E., Johnson, A.B. and Socha, M.T. (2000) Digital Characteristics in Commercial Dairy Herds Fed Metal-Specific Amino Acid Complexes. Journal of Dairy Science, 83, 1553-1572. http://dx.doi.org/10.3168/jds.S0022-0302(00)75028-4

[114] Ballantine, H.T., Socha, M.T., Tomlinson, D.J., Johnson, A.B., Fielding, A.S., Shearer, J.K. and Van Amstel, S.R. (2002) Effects of Feeding Complexed Zinc, Manganese, Copper, and Cobalt to Late Gestation and Lactating Dairy Cows on Claw Integrity, Reproduction, and Lactation Performance. Professional Animal Scientist, 18, 211-218. http://dx.doi.org/10.15232/S1080-7446(15)31524-2

[115] Wedekind, K.J., Hortin, A.E. and Baker, D.H. (1992) Methodology for Assessing Zinc. Bioavailability: Efficacy Estimates for Zinc-Methionine, Zinc Sulfate, and Zinc Oxide. Journal of Animal Science, 70, 178-187. http://dx.doi.org/10.2527/1992.701178x

[116] Paripatanonont, T. and Lovell, R.T. (1994) Chelated Zinc Reduces the Dietary Zinc Requirement of Channel Catfish, Ictalurus punctatus. Aquaculture, 133, 73-82. http://dx.doi.org/10.1016/0044-8486(94)00404-C

[117] Prohaska, J.R. and Failla, M.L. (1993) Copper and Immunity. In: Klurfeld, D.M., Ed., Human Nutrition-A Comprehensive Treatsie, Plenum Press, New York, Vol. 8, 309-332. http://dx.doi.org/10.1007/978-1-4615-2900-2_15

[118] Torre, P.M., Harmon, R.J., Hemken, R.W., Clark, T.W., Trammell, D.S. and Smith, B.A. (1996) Mild Dietary Copper Insufficiency Depresses Blood Neutrophil Function in Dairy Cattle. Journal of Nutritional Immunology, 4, 3-24.

[119] Chandra, R.K. (1980) Acrodermatitis Enterpathica: Zinc Levels and Cell-Mediated Immunity. Pediatrics, 66, 789-791.

[120] Jones, D.G. and Suttle, N.F. (1981) Some Effects of Copper Deficiency and Leukocyte Function in Sheep and Cattle. Research in Veterinary Science, 31, 151-156. 
[121] Wright, C.L., Spears, J.W., Brown, T.T., Lloyd, K.E. and Tiffany, M.E. (2000) Effects of Chromium and Copper on Performance and Immune Function of Stressed Steers. Journal of Animal Science, 78, 1.

[122] Spears, J.W. (2000) Micronutrients and Immune Function in Cattle. Nutrition Society, 59, 587-594. http://dx.doi.org/10.1017/S0029665100000835

[123] Chesters, J.K. (1997) Zinc. In: O’Dell, B.L. and Sunde, R.A., Eds., Handbook of Nutritionally Essential Mineral Elements, Marcel Dekker Inc., New York, 185-230.

[124] Chandra, R.K. and Newberne, P.M. (1977) Nutrition, Immunity, and Infection, Mechanism of Interactions. Plenum, New York. http://dx.doi.org/10.1007/978-1-4684-0784-6

[125] Vyas, D. and Chandra, R.K. (1983) Thymic Factor Activity Lymphocyte Stimulation Response and Antibody-Forming Cells in Copper Deficiency. Nutrition Research, 3, 343-350. http://dx.doi.org/10.1016/S0271-5317(83)80084-0

[126] Nedyjlkov, K. and Krustev, E. (1969) The Application of Zinc in the Control of Cowsterility. Veterinary Medical Nauk, 6, 79.

[127] Wilson, J.G. (1966) Bovine Functional Infertility in Devon and Cornwall: Response to Manganese Therapy. Veterinary Record, 98, 115.

[128] Keen, C., Lonerdal, B. and Hurley, L.S. (1984) Manganese. In: Freiden, E., Ed., Biochemistry of the Essential Ultratrace Elements, Plenum, New York, 89-132.

http://dx.doi.org/10.1007/978-1-4684-4775-0_5

\section{Submit or recommend next manuscript to SCIRP and we will provide best service for you:}

Accepting pre-submission inquiries through Email, Facebook, LinkedIn, Twitter, etc.

A wide selection of journals (inclusive of 9 subjects, more than 200 journals)

Providing 24-hour high-quality service

User-friendly online submission system

Fair and swift peer-review system

Efficient typesetting and proofreading procedure

Display of the result of downloads and visits, as well as the number of cited articles

Maximum dissemination of your research work

Submit your manuscript at: http://papersubmission.scirp.org/

Or contact ojas@scirp.org 